Article

\title{
$\alpha$-Lipoic Acid Inhibits IL-8 Expression by Activating Nrf2 Signaling in Helicobacter pylori-infected Gastric Epithelial Cells
}

\author{
Seoyeon Kyung, Joo Weon Lim and Hyeyoung Kim * [D \\ Department of Food and Nutrition, Brain Korea 21 PLUS Project, College of Human Ecology, Yonsei University, \\ Seoul 03722, Korea; loveminb@naver.com (S.K.); jwlim11@yonsei.ac.kr (J.W.L.) \\ * Correspondence: kim626@yonsei.ac.kr; Tel.: +82-2-2123 3125; Fax: +82-2-364-5781
}

Received: 20 September 2019; Accepted: 18 October 2019; Published: 19 October 2019

\begin{abstract}
Helicobacter pylori (H. pylori) causes gastritis and gastric cancers. Oxidative stress is involved in the pathological mechanism of $H$. pylori-induced gastritis and gastric cancer induction. Therefore, reducing oxidative stress may be beneficial for preventing the development of $H$. pylori-associated gastric diseases. Nuclear factor erythroid-2-related factor 2 (Nrf2) is a crucial regulator for the expression of antioxidant enzyme heme oxygenase-1 (HO-1), which protects cells from oxidative injury. $\alpha$-Lipoic acid ( $\alpha$-LA), a naturally occurring dithiol, shows antioxidant and anti-inflammatory effects in various cells. In the present study, we examined the mechanism by which $\alpha$-LA activates the Nrf2/HO-1 pathway, suppresses the production of pro-inflammatory cytokine interleukine-8 (IL-8), and reduces reactive oxygen species (ROS) in H. pylori-infected AGS cells. $\alpha$-LA increased the level of phosphorylated and nuclear-translocated Nrf2 by decreasing the amount of Nrf2 sequestered in the cytoplasm by complex formation with Kelch-like ECH1-associated protein 1 (KEAP 1). By using exogenous inhibitors targeting Nrf2 and HO-1, we showed that up-regulation of activated Nrf2 and of HO- 1 results in the $\alpha$-LA-induced suppression of interleukin 8 (IL-8) and ROS. Consumption of $\alpha$-LA-rich foods may prevent the development of $H$. pylori-associated gastric diseases by decreasing ROS-mediated IL-8 expression in gastric epithelial cells.
\end{abstract}

Keywords: $\alpha$-lipoic acid; Helicobacter pylori; interleukine-8; nuclear factor erythroid-2-related factor 2; heme oxygenase- 1

\section{Introduction}

$\alpha$-Lipoic acid ( $\alpha$-LA) is an endogenous dithiol found in small quantities in all foods but is slightly enriched in spinach, broccoli and some meats [1]. $\alpha$-LA is widely used as a dietary supplement because it is regarded as an ideal antioxidant agent owing to its ability to scavenge free radicals, chelate transition metal ions, and up-regulate the expression of antioxidant genes [2]. $\alpha$-LA has been shown to confer a protective effect against various diseases, including Alzheimer's disease and diabetes [3-6]. Oral administration of $\alpha$-LA has modulated insulin sensitivity in patients with type-2 diabetes mellitus [3,4]. $\alpha$-LA treatment has improved cognitive functioning in patients with Alzheimer's disease [5,6]. Thus, determination of the action mechanism(s) of $\alpha$-LA is of special importance.

In previous work focusing on the effect of $\alpha$-LA on Helicobacter pylori (H. pylori) infection-induced oxidative stress in gastric epithelial cells, we showed that $\alpha$-LA decreases ROS levels and suppresses NADPH oxidase activity and the inflammatory signaling pathways mediated by mitogen-activated protein kinases, janus kinase/signal transducers and activators of transcription (JAK/STAT) and nuclear factor kappa light chain enhancer of activated B cells (NF-kB) $[7,8]$. In the present study, we have focused on the effect of $\alpha$-LA on nuclear factor erythroid 2-related factor 2 (Nrf2), which is a crucial 
transcriptional regulator of antioxidant enzymes such as heme oxygenase-1 (HO-1), thioredoxins and peroxiredoxins (Prxs) [9].

Nrf2 is retained in the cytoplasm at low levels by the redox-sensor Kelch-like ECH-associated protein 1 (KEAP 1), which in turn facilitates Nrf2 ubiquitination and subsequent degradation [10]. Oxidative stress results in release of Nrf2 from KEAP 1, which allows Nrf2 to translocate to the nucleus where it binds to antioxidant response elements (AREs) [11]. AREs are sites within promoter regions of genes that bind transcriptional factors such as Nrf2 and thereby facilitate the expression of genes encoding phase II detoxification enzymes and anti-oxidant enzymes such as HO-1 [12]. High levels of ROS-scavenging enzymes were frequently found in cancer cells. Mutant KEAP 1 is present in non-small-cell lung cancer (NSCLC) cell lines and in NSCLC patients, which leads to constitutive activation of Nrf2 function and cytoprotection against ROS-generating radiotherapy and chemotherapeutic agents [13].

The anti-oxidant effect of HO-1 has been demonstrated for a variety cell types. For example, the proton pump-inhibitor, lansoprazole, exerts its anti-inflammatory effect in gastric mucosal cells by inducing HO-1 expression via Nrf2 activation and KEAP 1 oxidation [14]. The antioxidant curcumin exerts its antioxidant and anti-inflammatory effects in vascular epithelial cells by up-regulating HO-1 expression [15]. Likewise, the anti-oxidant $\alpha$-LA protects monocytes [16] and retinal neuronal cells [17] from oxidative stress by up-regulating $\mathrm{HO}-1$ expression.

H. pylori is a Gram-negative bacterium, usually acquired during childhood, whose natural habitat is the gastric lumen. H. pylori is accepted as the most important cause of gastritis and peptic ulcer in humans [18]. Furthermore, its important role in the pathogenesis of gastric cancer as well as in several extra-gastroduodenal diseases has been confirmed $[19,20]$. Oxidative stress is an important component of $H$. pylori-induced chronic infection [21]. This bacterium colonizes human gastric mucosa by infiltration of neutrophils into the epithelial cell layer. This process is dependent on the production of pro-inflammatory cytokines, especially the chemotactic cytokine interleukine-8 (IL-8). The expression of IL-8 varies depending on the density or strain of $H$. pylori that infects the host cells [22]. IL-8 acts as a powerful mediator of the inflammatory response by activating and attracting neutrophils, basophils and T cells to the site of infection [23,24]. This generates high levels of ROS at the site [25], which in turn causes oxidative stress-induced gastric damage [26]. Several studies have demonstrated that the ROS produced by H. pylori mediates the expression of IL-8 [27-29]. Therefore, therapeutic agents that inhibit ROS production or that scavenge ROS could serve in the treatment of $H$. pylori-associated gastric mucosal inflammation.

The purpose of the present study is to determine the mechanism(s) by which $\alpha$-LA inhibits ROS-mediated expression of pro-inflammatory cytokine IL-8 in H. pylori-infected gastric epithelial cells. Herein, we report experimental evidence for $\alpha$-LA-induced reduction in ROS and IL- 8 and up-regulation of HO-1 via Nrf2 activation in H. pylori-infected gastric epithelial AGS cells.

\section{Materials and Methods}

\subsection{Reagents}

$\alpha$-LA (R- $\alpha$-LA) and a Nrf2 inhibitor, trigonelline, were purchased from Sigma-Aldrich (St. Louis, MO, USA) and were dissolved in $0.5 \mathrm{M}$ ethanol and distilled water, respectively. A HO-1 inhibitor protoporphyrin (ZnPP) was purchased from Santa Cruz Biotechnology (sc-2000329, Santa Cruz Biotechnology, Santa Cruz, CA, USA) and was dissolved in dimethyl sulfoxide (DMSO).

\subsection{Cell Line and Culture Conditions}

Gastric epithelial AGS cells (gastric adenocarcinoma, ATCC CRL 1739, Rockvile, MD, USA) were purchased from the American Type Culture Collection (Rockvile, MD, USA). The cells were grown in RPMI 1640 medium (GIBCO, Grand Island, NY, USA) supplemented with 10\% fetal bovine serum, 
$2 \mathrm{mM}$ glutamine, $100 \mathrm{U} / \mathrm{mL}$ penicillin, and $100 \mu \mathrm{g} / \mathrm{mL}$ streptomycin (Sigma-Aldrich, St. Louis, MO, USA). The cells were grown under a humidified atmosphere of $95 \%$ air and $5 \% \mathrm{CO}_{2}$ at $37^{\circ} \mathrm{C}$.

\subsection{Cell Culture with H. pylori Infection}

H. pylori, strain NCTC 11637, was obtained from the American Type Culture Collection. The bacterium was grown under microaerophilic conditions at $37^{\circ} \mathrm{C}$, using an anaerobic chamber (BBL Campy Pouch System, Becton Dickinson Microbiology Systems, Franklin Lakes, NJ, USA).

AGS cells were seeded and cultured overnight to reach $80 \%$ confluency. Prior to H. pylori infection, the cells were washed once with culture medium containing no antibiotics. Whole H. pylori was suspended in antibiotic-free RPMI 1640 medium supplemented with $10 \%$ fetal bovine serum, and then treated to the AGS cells. The ratio of AGS cell: H. pylori was 1:100. The ratio of AGS cell: H. pylori, 1:100, was adapted from our previous study showing high expression of IL-8 in gastric epithelial AGS cells infected with H. pylori, NCTC11637 [30].

\subsection{Experimental Protocol}

To investigate the effect of $\alpha$-LA on Nrf2 activation, dissociation of KEAP1-Nrf2 complex, nuclear translocation of Nrf2, and HO-1 expression, the AGS cells $\left(5 \times 10^{4} / \mathrm{mL}\right)$ were treated with a solution of $\alpha$-LA in $0.5 \mathrm{M}$ ethanol to produce a final $\alpha$-LA concentration of $5 \mu \mathrm{M}$ and cultured for $2 \mathrm{~h}$ (for the determination of the KEAP 1-Nrf2 complex and nuclear translocation of Nrf2) and for $8 \mathrm{~h}$ (for determination of KEAP 1, HO-1 and phosphorylated and total Nrf2 in whole-cell extracts or nuclear extracts).

To determine the effect of $\alpha$-LA on the expression of IL- 8 and HO- 1 and ROS levels, AGS cells were treated with $\alpha$-LA (at final concentrations of 2.5 and $5 \mu \mathrm{M}$ ) for $2 \mathrm{~h}$ and incubated with $H$. pylori for $1 \mathrm{~h}$ (for the determination of HO-1 and ROS), $12 \mathrm{~h}$ (for IL-8 mRNA), and $24 \mathrm{~h}$ (for IL-8).

To assess the involvement of Nrf2 and HO- 1 in the inhibitory effect of $\alpha$-LA on H. pylori-induced IL-8 expression, the cells were treated with trigonelline $(1 \mu \mathrm{M})$ or $\mathrm{ZnPP}(2 \mu \mathrm{M})$ in the presence of $\alpha$-LA $(5 \mu \mathrm{M})$ and incubated with $\mathrm{H}$. pylori for $1 \mathrm{~h}$ (for the determination of HO-1 and ROS), $12 \mathrm{~h}$ (for IL-8 mRNA), and $24 \mathrm{~h}$ (for IL-8). For each experiment, the amount of a vehicle was less than $0.5 \%$. A control, in which the vehicle alone was added, was carried out in parallel.

\subsection{Measurement of Intracellular ROS Levels}

The cells were treated with $10 \mu \mathrm{g} / \mathrm{mL}$ of dichlorofluorescein diacetate (DCF-DA; Sigma-Aldrich) and incubated for $30 \mathrm{~min}$ under an atmosphere of $5 \% \mathrm{CO}_{2} / 95 \%$ air at $37^{\circ} \mathrm{C}$. The intensities of DCF fluorescence at $535 \mathrm{~nm}$ (excitation at $495 \mathrm{~nm}$ ) were measured with a Victor 5 multi-label counter (PerkinElmer Life and Analytical Sciences, Boston, MA, USA). The intracellular ROS levels were normalized to cell numbers and expressed as the relative increase.

\subsection{Real-time PCR Analysis}

Cellular RNA was isolated by using the reagent TRI (Molecular Research Center, Inc., Cincinnati, $\mathrm{OH}, \mathrm{USA}$ ). The RNA was converted to cDNA by reverse transcription using a random hexamer as template, MuLV reverse transcriptase (Promega, Madison, WI, USA) as catalyst and the reaction conditions: $23{ }^{\circ} \mathrm{C}$ for $10 \mathrm{~min}, 37^{\circ} \mathrm{C}$ for $60 \mathrm{~min}$ and $95{ }^{\circ} \mathrm{C}$ for $5 \mathrm{~min}$. The cDNA was used for real-time PCR. The IL-8 primers 5'-ATGACTTCCAAGCTGGCCGTGGCT-3' (forward primer) and 5'-TCTCAGCCCTCTTCAAAAACTTCT-3' (reverse primer) were used to generate a $297 \mathrm{bp}$ PCR product. For $\beta$-actin, the forward primer used is $5^{\prime}$-ACCAACTGGGACGACATGGAG-3' and the reverse primer used is $5^{\prime}$-GTGAGGATCTTCATGAGGTAGTC-3', giving a 349 bp PCR product. cDNA was amplified by 45 repeat denaturation cycles at $95^{\circ} \mathrm{C}$ for $30 \mathrm{~s}$, annealing at $55^{\circ} \mathrm{C}$ for $30 \mathrm{~s}$, and extension at $72^{\circ} \mathrm{C}$ for $30 \mathrm{~s}$. During the first cycle, the $95^{\circ} \mathrm{C}$ step was extended to $3 \mathrm{~min}$. The $\beta$-actin gene was amplified in the same manner to serve as the reference gene. 


\subsection{Enzyme-Linked Immunosorbent Assay (ELISA)}

The AGS cells $\left(1.5 \times 10^{5} /\right.$ well $)$ were seeded in 6-well plates. The culture medium was centrifuged at $15,000 \mathrm{rpm}$ for $15 \mathrm{~min}$ at $4{ }^{\circ} \mathrm{C}$. The supernatant was collected for quantitating IL-8 with an enzyme-linked immunosorbent assay (ELISA) kit (Invitrogen Corporation, Carlsbad, CA, USA) according to the manufacturer's instructions.

\subsection{Preparation of Whole-Cell Extracts and Nuclear Extracts}

Cells were harvested into phosphate buffered saline (PBS) and pelleted by centrifugation at $5000 \times \mathrm{g}$ for $15 \mathrm{~min}$. The cell pellets were re-suspended in lysis buffer containing $10 \mathrm{mM}$ Tris (pH 7.4), $1 \%$ NP-40 and a commercial protease inhibitor complex (Complete; Roche, Mannheim, Germany). Cells were lysed through a $1 \mathrm{~mL}$ syringe using several rapid strokes. The lysates were centrifuged at $13,000 \times g$ for $15 \mathrm{~min}$. The supernatants were used as whole-cell extracts. To prepare the nuclear extracts, the cell pellets were re-suspended with $30 \mu \mathrm{L}$ of hypotonic buffer containing $10 \mathrm{mM}$ HEPES (pH 7.9), $1.5 \mathrm{mM} \mathrm{MgCl}_{2}, 10 \mathrm{mM} \mathrm{KCl}, 0.5 \mathrm{mM}$ DTT, $0.5 \mathrm{mM}$ PMSF, and $0.2 \%$ NP-40. The extracts were centrifuged at $13,000 \times \mathrm{g}$ and $4{ }^{\circ} \mathrm{C}$ for $20 \mathrm{~min}$. The pellets were re-suspended in $30 \mu \mathrm{L}$ of extraction buffer containing $20 \mathrm{mM}$ HEPES (pH 7.9), $420 \mathrm{mM} \mathrm{NaCl}, 0.2 \mathrm{mM}$ EDTA, $1.5 \mathrm{mM} \mathrm{MgCl}$, 25\% glycerol, $0.5 \mathrm{mM}$ DTT, and $0.5 \mathrm{mM}$ PMSF. After centrifugation at $13,000 \times \mathrm{g}$ and $4{ }^{\circ} \mathrm{C}$ for $20 \mathrm{~min}$, the supernatants were used as the nuclear extracts. Bradford assay (Bio-Rad Laboratories, Hercules, CA, USA) was used for determination of protein.

\subsection{Western Blot Analysis}

Whole-cell extracts (6-40 $\mu \mathrm{g} /$ per lane) were loaded onto $8-10 \%$ SDS polyacrylamide gels and separated by electrophoresis under reducing conditions. The proteins were then transferred by electroblotting and verified by using reversible staining with Ponceau $\mathrm{S}$. The membranes were blocked using 3\% non-fat dry milk in TBS-T (Tris-buffered saline and $0.2 \%$ Tween 20). The proteins were detected with antibodies for Nrf2 (sc-722, Santa Cruz Biotechnology, Dallas, TX, USA), p-Nrf2 (ab76026, Abcam, Cambridge, UK), KEAP 1 (sc-365626, Santa Cruz Biotechnology), and HO-1 (ADI-SPA-895, Enzo Life Science Inc., Farmingdale, NY, USA). The antibodies were diluted in TBS-T containing 3\% dry milk and incubated with the membrane overnight at $4{ }^{\circ} \mathrm{C}$. After washing with TBS-T, primary antibodies were detected with horseradish peroxidase-conjugated secondary antibodies (anti-rabbit, anti-mouse, anti-goat) and visualized by using the enhanced chemiluminescence detection system (Santa Cruz Biotechnology, Dallas, TX, USA) and BioMax MR film (Kodak, Rochester, NY, USA). The protein levels were compared to that of the loading control actin, or histone H1.

\subsection{Immunoprecipitation of the Nrf2-KEAP 1 Complex}

$\alpha$-LA $(5 \mu \mathrm{M})$-treated and untreated AGS cells were lysed in $500 \mu \mathrm{M}$ of immunoprecipitation buffer containing $10 \mathrm{mM}$ Tris- $\mathrm{HCl}$ (pH 7.4), $100 \mathrm{mM} \mathrm{NaCl}, 1 \mathrm{mM}$ EDTA, 1 mM EGTA, Complete, 0.5\% NP-40, $0.5 \%$ sodium deoxycholate, and $10 \%$ glycerol. Then, cells were centrifuged at $15,000 \times g$ for $15 \mathrm{~min}$. Polylconal antibody and protein G-agarose were added to the cleared supernatant, and the mixture was incubated overnight at $4{ }^{\circ} \mathrm{C}$. The protein G-antibody-antigen complex was then collected by washing four times with immunoprecipitation buffer containing $150 \mathrm{mM} \mathrm{NaCl}, 10 \mathrm{mM}$ Tris- $\mathrm{HCl}$ (pH 7.4), 1 mM EDTA, 1 mM EGTA, $0.5 \%$ NP- 40 , and $0.5 \%$ sodium deoxycholate. The pellet was resuspended in $50 \mu \mathrm{L}$ of SDS sample buffer and boiled for $10 \mathrm{~min}$. The preparation was then subjected to Western blot analysis.

\subsection{Immunofluorescence Staining}

The cells were treated with $\alpha$-LA for $2 \mathrm{~h}$ on slide glasses and then fixed with cold $100 \%$ methanol. The fixed cells were permeabilized with $0.1 \%$ Triton X-100 in PBS for $5 \mathrm{~min}$, blocked with $0.1 \%$ gelatin and $1 \%$ bovine serum albumin in PBS for $1 \mathrm{~h}$, and then incubated for $1 \mathrm{~h}$ with the primary antibody 
for Nrf2. After washing with PBS, the cells were incubated with rhodamine-conjugated mouse anti-rabbit IgG antibody (sc-2492, Santa Cruz Biotechnology) for $1 \mathrm{~h}$. After removal of the secondary antibody, the cells were washed with PBS and covered with the antifade medium Vectashield containing 4',6-diamidino-2-phenylindole (DAPI). The preparations were stored for $30 \mathrm{~min}$ to allow saturation with DAPI. The cells stained with Rhodamine-conjugated antibody were examined with a laser scanning confocal microscope (Zeiss LSM 880, Carl Zeiss Inc., Thornwood, NY, USA) and photographed.

\subsection{Statistical Analysis}

One-way ANOVA and Newman-Keul's post-hoc test were used. All results are expressed as the mean \pm S.E. of four different experiments. A $p$-value of 0.05 or less was considered to be statistically significant.

\section{Results}

3.1. $\alpha$-LA Increases Expression, Phosphorylation, and Nuclear Translocation of Nrf2, and Expression of HO-1 in AGS Cells

Prior to determining the effect of $\alpha$-LA on $H$. pylori-infected cells, we measured the effect of $\alpha$-LA on uninfected cells. Firstly, we measured $\alpha$-LA-induced changes in Nrf2 expression, phosphorylation, and nuclear translocation. Accordingly, Western blot analysis of whole-cell extracts and of nuclear extracts was carried out using AGS cells treated with $\alpha$-LA for 2, 4 and $8 \mathrm{~h}$. Figure 1A shows that the level of Nrf2 in the whole-cell extracts increased in a time-dependent manner over the $8 \mathrm{~h}$ period. In contrast, the level of p-Nrf2 in the whole-cell extracts, and Nrf2 in the nuclear extracts, reached a maximum at $2 \mathrm{~h}$ and then declined in a time-dependent manner (Figure 1A). In order to verify the impact of $\alpha$-LA on Nrf2 nuclear translocation, AGS cells were incubated with $\alpha$-LA for $2 \mathrm{~h}$ and then subjected to immunofluorescence staining. Whereas the level of the nuclear marker DAPI was not changed by $\alpha$-LA, the level of Nrf2 in the nucleus was increased by $\alpha$-LA (Figure 1B).

Next, the impact of $\alpha$-LA on the expression KEAP 1 and HO- 1 was examined by Western blot analysis of whole-cell extracts. As shown in Figure 1A, the levels of KEAP 1 and HO-1 were increased in a time-dependent manner over the $8 \mathrm{~h}$ period. These results indicated that $\alpha$-LA activates Nrf2, and that this activation up-regulates HO-1 expression. Because KEAP 1 sequesters Nrf2 in the cytoplasm, we carried an additional experiment (see below) to determine if $\alpha$-LA alters the level of the Nrf2-KEAP 1 complex.

\section{2. $\alpha$-LA Decreases Interaction between KEAP1 and Nrf2 in AGS Cells}

The impact of $\alpha$-LA on the level of Nrf2-KEAP 1 association in AGS cells was examined by carrying out immunoprecipitation (IP) of the complex with anti-KEAP 1 antibody or anti-Nrf2 antibody followed by Western blot analysis (WB) using anti-Nrf2 antibody and anti-KEAP 1 antibody, respectively. The results obtained for cells treated with $\alpha$-LA for $2 \mathrm{~h}$ are reported in Figure 1C, along with the results obtained for the control experiment ("None") in which $\alpha$-LA was excluded. Whereas the treatment of cells with $\alpha$-LA increased the level of KEAP 1 and Nrf2 present in whole-cell extracts (Figure 1C, lower panel), it decreased the level of KEAP 1 and Nrf2 present in the immunoprecipitate (Figure 1C, upper panel). This finding indicates that $\alpha$-LA can increase Nrf2 activity by inhibiting KEAP 1-mediated sequestration of Nrf2.

\section{3. $\alpha$-LA Decreases IL-8 Expression and ROS Levels, but Increases HO-1 Expression in H. pylori-infected AGS Cells}

As shown in Figure 2, H. pylori infection increased IL-8 gene expression at the mRNA (Figure 2A) and protein (Figure 2B) levels. However, pretreatment of the cells with $\alpha$-LA significantly reduced these increases in a dose-dependent manner. In addition, whereas H. pylori infection lowered the HO-1 
level, treatment of the cells with $\alpha$-LA prior to infection resulted in a net increase in the HO-1 level (Figure 2C).

Next, we compared the levels of ROS in H. pylori-infected AGS cells pretreated with $\alpha$-LA, using $\alpha$-LA-untreated and H. pylori-infected cells as the control. Figure 2D shows that $\alpha$-LA reduced, in a dose dependent manner, the up-regulation of ROS in H. pylori-infected AGS cells. Together, these findings suggest that $\alpha$-LA reduces oxidative stress in $H$. pylori-infected cells by reducing ROS and IL-8 and increasing HO-1 in AGS cells.
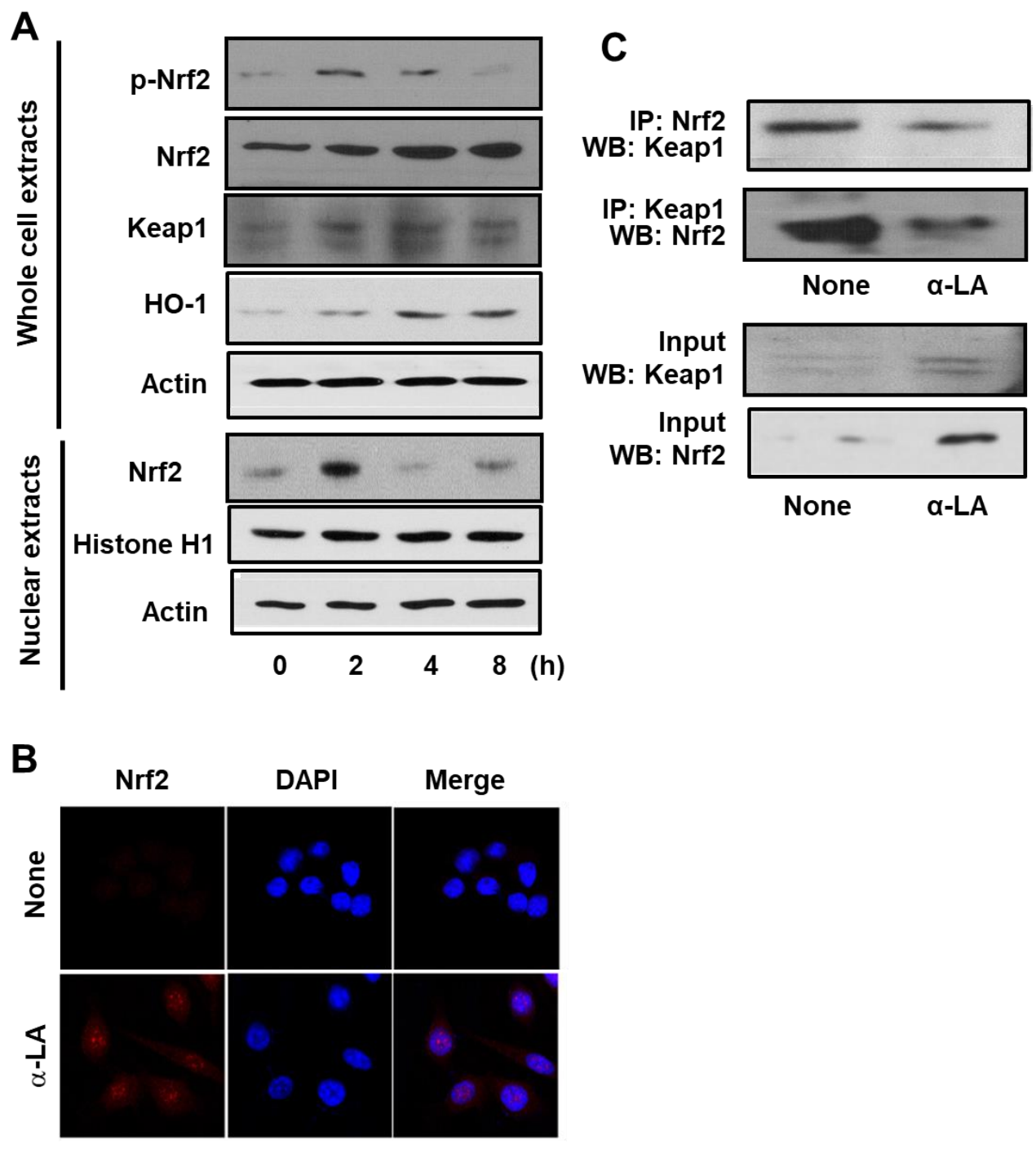

Figure 1. Determination of the impact of $\alpha$-LA on the levels of activated Nrf2, KEAP 1-bound Nrf2, KEAP 1, and HO-1 in AGS cells. (A) Western blots of whole-cell extracts (upper panel) or nuclear extracts (bottom panel) with actin serving as the loading control and histone H1 serving as the index for the nuclear extracts. The cells were treated with $5 \mu \mathrm{M} \alpha$-LA for the indicated time periods. (B) Confocal microscope images of AGS cells treated with $5 \mu \mathrm{M} \alpha$-LA for $2 \mathrm{~h}$ followed by immunofluorescence staining of the fixed cells. Nrf2 was visualized using fluorescein rhodamin-conjugated anti-rabbit IgG antibody (red) with DAPI counter staining (blue) of the same field. "None" refers to the cells treated with the vehicle for $\alpha$-LA ( $0.5 \mathrm{M}$ ethanol) alone. (C) Western blots of whole-cell extracts (lower panel) and whole-cell extract-derived immunoprecipitates obtained using the anti-Nrf2 and anti-KEAP 1 antibodies for precipitation (IP) and visualization (WB; western blot analysis) as indicated (upper panel). The cells were treated with $5 \mu \mathrm{M} \alpha$-LA for $2 \mathrm{~h}$. Input is used as the control for protein expression. "None" refers to the cells treated with the vehicle for $\alpha$-LA ( $0.5 \mathrm{M}$ ethanol) only. 

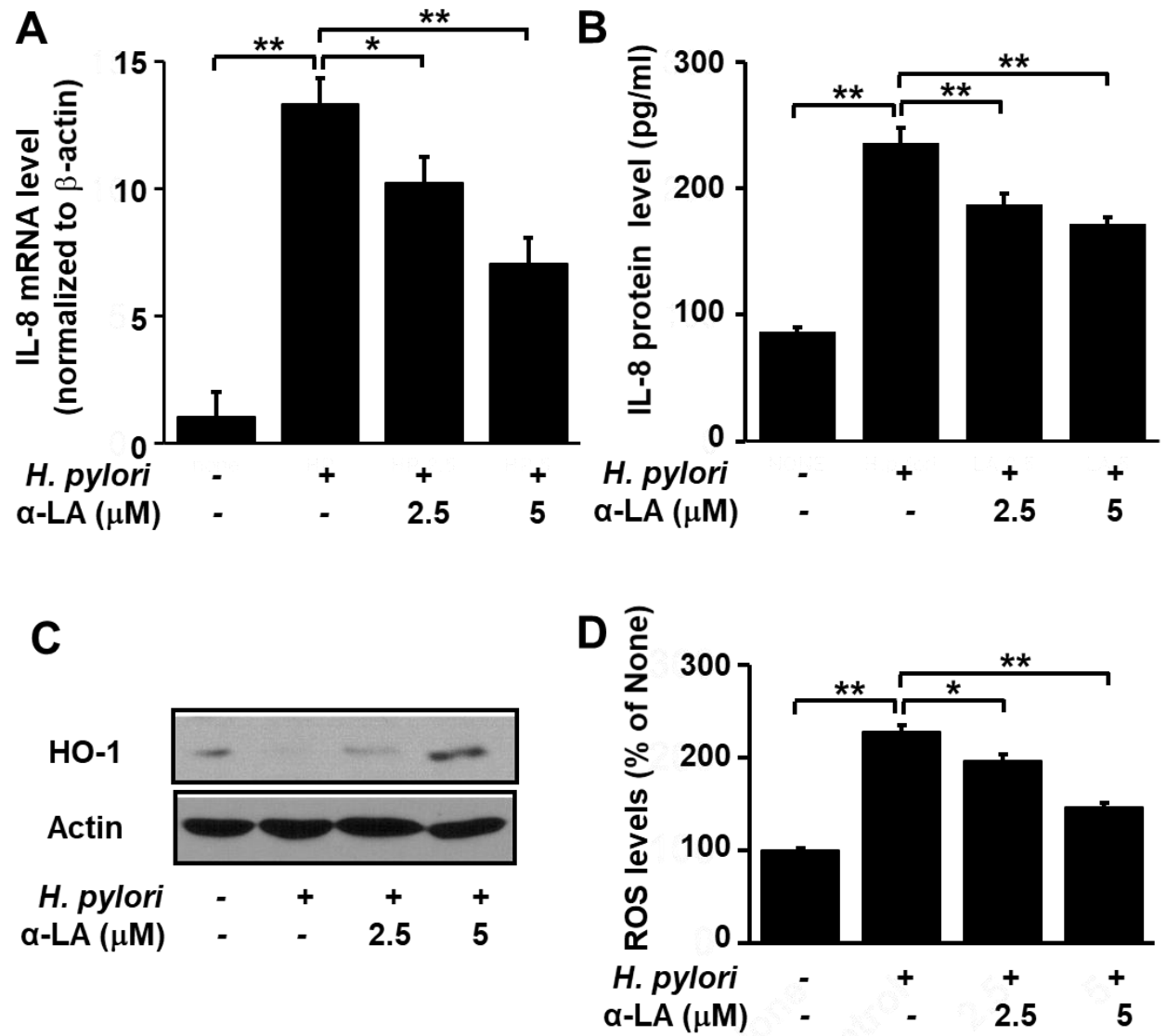

Figure 2. Determination of the impact of $\alpha$-LA on the levels of HO-1, IL-8 and ROS in H. pylori-infected AGS cells. The cells were pretreated with the indicated concentration of $\alpha$-LA for $8 \mathrm{~h}$, before infection with H. pylori. (A) The amount of IL-8 mRNA determined by real-time PCR analysis and normalized to actin mRNA. (B) The quantity of IL-8 in the cell culture medium determined by ELISA. Data are expressed as the mean \pm S.E. of four different experiments. (C) Western blot of whole-cell extracts using $\beta$-actin as the loading control. (D) ROS levels determined by fluorescent DCF. Intracellular ROS is expressed as the relative increase. The value for cells without $H$. pylori infection in the absence of $\alpha$-LA treatment is set as $100 \%{ }^{*} p<0.05,{ }^{* *} p<0.01$.

3.4. Nrf2 Inhibitor Trigonelline Abolishes the Effect of $\alpha$-LA on IL-8, HO-1 and ROS Levels in H. pylori-infected AGS Cells

Having shown that $\alpha$-LA reduces the levels of ROS and IL- 8 , and increases the level of HO-1, in $H$. pylori-infected AGS cells, we next turned our attention to determining if these effects are the result of the $\alpha$-LA-induced activation of Nrf2 observed with the uninfected cells (Figure 1). For this purpose, the Nrf2 inhibitor trigonelline was used to block the effect of $\alpha$-LA-induced Nrf2 activation. Figure 3A and $3 \mathrm{~B}$ show that in the presence of the inhibitor, the capacity for $\alpha$-LA to diminish the H. pylori-induced increase in IL-8 gene expression at the mRNA level (Figure 3A) and protein level (Figure 3B) was reduced. Likewise, trigonelline diminished the $\alpha$-LA-induced increase in HO-1 expression (Figure 3C), as well as the $\alpha$-LA-induced decrease in ROS (Figure 3D). These findings support the role of Nrf2 in mediating $\alpha$-LA-induced down-regulation of IL-8 and ROS and up-regulation of $\mathrm{HO}-1$ in $H$. pylori-infected AGS cells.

3.5. HO-1 Inhibitor ZnPP Inhibits the Effect of $\alpha$-LA on ROS Levels and Expression of IL-8 in H. pylori-infected AGS Cells

Having shown that $\alpha$-LA increases the level of HO-1 in AGS cells in which HO-1 levels were reduced as a result of the $H$. pylori infection, we carried out experiments to test whether the $\alpha$-LA-induced 
decrease in ROS and IL-8 resulting from $H$. pylori infection is the result of the $\alpha$-LA-induced increase in HO-1. Accordingly, infected AGS cells were treated with $\alpha$-LA in the presence and absence of the $\mathrm{HO}-1$ inhibitor ZnPP. Figure 4 shows that ZnPP suppressed the $\alpha$-LA-induced decrease in ROS levels (Figure 4A) and decrease in IL-8 expression at both the mRNA (Figure 4B) and protein (Figure 4C) levels. These results demonstrate that $\alpha$-LA inhibits IL- 8 gene expression and reduces the ROS levels via up-regulation of HO-1 expression in H. pylori-infected cells.

A

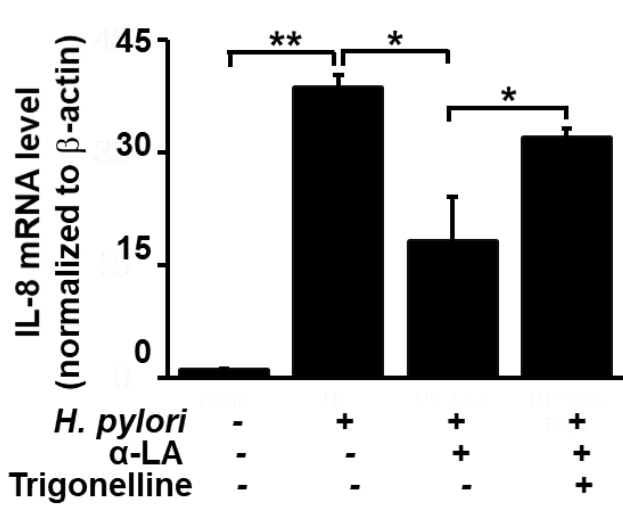

B

C

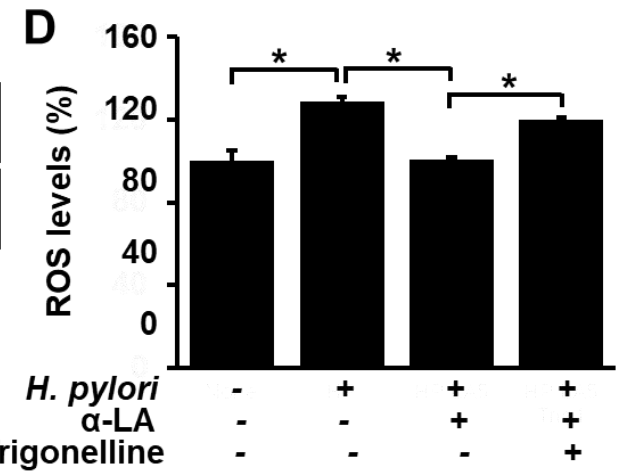

Figure 3. Determination of the impact of the Nrf2 inhibitor trigonelline on IL- 8 gene expression and ROS levels in $H$. pylori-infected AGS cells treated with $\alpha$-LA. The cells were treated with $5 \mu \mathrm{M} \alpha$-LA and $1 \mu \mathrm{M}$ trigonelline for $8 \mathrm{~h}$, and then infected with H. pylori. (A) The amount of IL- $8 \mathrm{mRNA}$ determined by real-time PCR analysis and normalized to cellular actin mRNA. (B) The amount of IL-8 in the culture medium determined by ELISA. Data are expressed as the mean \pm S.E. of three different experiments. (C) Western blot analysis for whole-cell extracts developed with anti-OH antibody. Actin was used as a loading control. (D) Cellular ROS levels determined by measuring the level of fluorescent DCF. The level of intracellular ROS is expressed as the relative increase. The value for cells without $H$. pylori infection in the absence of $\alpha$-LA is set as $100 \%$. ${ }^{*} p<0.05,{ }^{* *} p<0.01$. 

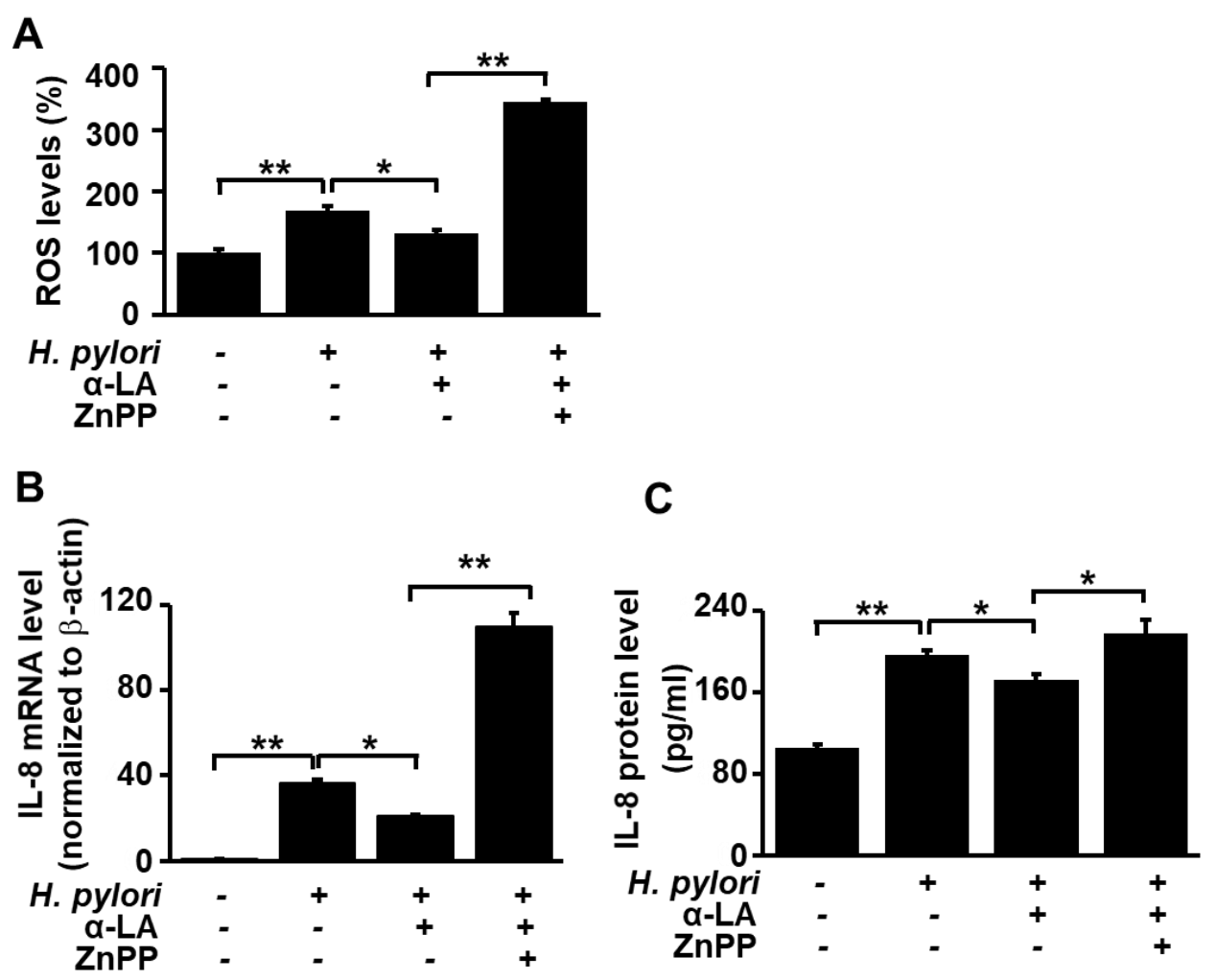

Figure 4. Determination of the impact of HO-1 inhibitor ZnPP on IL-8 gene expression and ROS levels in H. pylori-infected AGS cells treated with $\alpha$-LA. The cells were co-treated with $5 \mu \mathrm{M} \alpha$-LA and $2 \mu \mathrm{M}$ $\mathrm{ZnPP}$ for $8 \mathrm{~h}$ and then infected with $H$. pylori. (A) Cellular ROS levels determined by measuring the level of fluorescent DCF. The intracellular ROS is expressed as the relative increase. The value for cells without $H$. pylori infection in the absence of $\alpha$-LA was set as $100 \%$. (B) IL-8 mRNA levels determined by real-time PCR analysis and normalized to actin mRNA. (C) The level of IL-8 in cell culture medium determined by ELISA. Data are expressed as the mean \pm S.E. of three different experiments. ${ }^{*} p<0.05$, ** $p<0.01$.

\section{Discussion}

In the present study, we found that $\alpha$-LA activates the Nrf2/HO- 1 pathway by decreasing the interaction between Nrf2 and KEAP 1. We also discovered that the levels of the pro-inflammatory agents ROS and IL- 8 are reduced by $\alpha$-LA as a result of its activation the Nrf2/HO- 1 pathway. These findings are consistent with the results obtained from previous studies carried out with other disease models. In particular, a recent study demonstrated that $\alpha$-LA improved neurobehavioral function by up-regulation of Nrf2 expression and its downstream protein factors including HO-1 and quinine oxidoreductase-1 (NQO-1) after traumatic brain injury in rats [31]. In addition, $\alpha$-LA treatment decreased cell death and ROS production in urban particulate matter (UPM)-exposed fibroblasts via the Nrf2, HO-1, and NQO-1 pathways. Also, $\alpha$-LA treatment abrogated increases in IL-6 and IL-8 levels induced by UPM in nasal fibroblasts [32]. Moreover, it has been reported that $\alpha$-LA ameliorated hepatic steatosis in rats of diabetes fed with high fat by increasing antioxidant defense systems through Nrf2 and consequently decreasing oxidative stress and hepatic TNF- $\alpha$ [33]. Nab-paclitaxel is an anti-cancer drug, but its side effect, peripheral neuropathy, affects both the quality of life and the survival of cancer patients. Interestingly, $\alpha$-LA could prevent oxidative stress and peripheral neuropathy in Nab-paclitaxel-treated rats through the Nrf2 signaling pathway without diminishing chemotherapeutic effect [34]. In the studies on Nrf2 and KEAP 1, the Nrf2 activators sequestosome-1, 5,6-dihydrocyclopenta-1,2-dithiole-3-thione and sulforaphane activate Nrf2 by decreasing the interaction between Nrf2 and KEAP $1[35,36]$. 
Previous studies carried out with macrophages, dendritic cells, and gastric cancer cells have indicated that $H$. pylori infection up-regulates HO-1 expression, thereby providing a protective effect against increased levels of ROS [36-38]. In the present study, we observed that $H$. pylori infection of the gastric epithelial AGS cells results in HO-1 down-regulation, in agreement with the findings reported by Gobert et al. [39] The down-regulation of the Nrf2/HO-1 pathway observed with the AGS cell line can be attributed to the action of the heat-shock protein $\mathrm{B}(\mathrm{HspB})$ present in certain strains of $H$. pylori [40], including the strain NCTC11637 [40] used in our studies. Specifically, AGS cells transfected with the H. pylori HspB gene display increased levels of KEAP 1 and reduced expression of Nrf2 [41].

Previously, we showed that $\alpha$-LA inhibits the expression of IL- 8 in $H$. pylori-infected gastric epithelial AGS cells by suppressing inflammatory signaling pathways including those of mitogen-activated protein kinases, JAK/STAT and NF-kB [7]. We have also reported that $\alpha$-LA reduces ROS levels in $H$. pylori-infected AGS cells by suppressing the activation of NADPH oxidase [8]. The results of the present study define the role that the Nrf2/HO- 1 plays in $\alpha$-LA-induced reduction in ROS and IL-8 levels in H. pylori-infected AGS cells. We also found that the suppression of Nrf2-KEAP 1 complex formation is the mechanism by which $\alpha$-LA activates the Nrf2/HO- 1 pathway in $H$. pylori-infected AGS cells.

Trigonelline is an alkaloid and occurs in many plants including coffee [42]. It is a specific small-molecule Nrf2 inhibitor and inhibits cell migration through downregulation of Nrf2-dependent antioxidant enzymes' activity [43]. Inhibition of the Nrf2 transcription factor was observed by trigonelline which has the potential to be used in combination therapy of highly-resistant tumors such as pancreatic cancer [44].

$\mathrm{ZnPP}$ is a metabolite formed in the process of heme biosynthesis. The lack of iron leads to increased $\mathrm{ZnPP}$ formation in the blood. High levels of $\mathrm{ZnPP}$ in the blood play a role in the inhibition of HO-1, which is the rate-limiting enzyme in the heme degradation pathway [45]. Since inhibition of HO-1 by ZnPP suppresses tumor cell growth [46], ZnPP has been suggested as a useful agent for antitumor therapy [47]. Therefore, $\mathrm{ZnPP}$ has been used as a potent competitive inhibitor of HO-1 in experimental studies.

Regarding H. pylori strain, Yamaoka et al. [22] examined expression patterns of IL-8 using real-time PCR analysis and ELISA in gastric biopsy specimens of 192 patients. CagA gene was determined using PCR. They reported that $H$ pylori infection was associated with increased rate of mRNA expression of IL-8 and with increased mucosal level of IL-8. IL-8 levels were correlated with the density of $H$ pylori in both the antrum and corpus. Cag $A$ gene positive $H$ pylori infection was related to increased expression of IL-8 at mRNA and protein levels. NCTC 11637, a cagA-positive strain, was the first Helicobacter cultured and has been distributed through national reference culture collections to researchers throughout the world [48]. Therefore, cag A positive H. pylori strain, NCTC 11637, was used on the effect of $\alpha$-LA on IL-8 expression in the present study.

From the aspect of gastric cells, the human gastric adenocarcinoma AGS or MKN-28 cells, gastric carcinoma KATO III cells, and rat gastric mucosal cells (RGM-1 which is non-adenocarcinoma cells) have been used for studies on gastric diseases caused by $\mathrm{H}$. pylori infection. However, the majority of studies on cytokine responses to $H$. pylori infection in vitro have used AGS and MK-28 cells. The studies, using AGS or MKN-28 cells, showed different cellular responses to H. pylori. While H. pylori-infected AGS cells show rapid cell elongation within only a few $\mathrm{h}, \mathrm{MKN}-28$ cells respond with a clear delay [49]. In addition, AGS secretes significantly more IL-8 than MKN-28 [50]. Therefore, many studies that investigate a relationship between $\mathrm{H}$. pylori and inflammatory cytokine response have used AGS cells.

The concentration of $\alpha$-LA used in the present study is $5 \mu \mathrm{M}$. Several studies demonstrated that the administration of $\alpha$-LA at a dose of $600 \mathrm{mg}$ improved insulin sensitivity in patients with type 2 diabetes mellitus and cognitive functions in patients with Alzheimer's Disease [3-6]. Ikuta et al. [51] showed that the plasma concentration of $\alpha$-LA after a single oral administration of $600 \mathrm{mg}$ of $\alpha$-LA in healthy humans was $1.68 \mu \mathrm{g} / \mathrm{mL}$ (approximately $8.1 \mu \mathrm{M}$ ). Therefore, $5 \mu \mathrm{M} \alpha$-LA used in this study is physiologically relevant. In addition, the effect of pretreatment with $\alpha$-LA on $H$. pylori-induced IL8 
expression in gastric epithelial cells was determined in the present study. Therefore, the results are relevant to prevention against $H$. pylori infection.

Our findings support the hypothesis that consumption of $\alpha$-LA-rich foods might prevent the development of $H$. pylori-induced gastric inflammation by decreasing ROS-mediated IL-8 expression through the Nrf2/HO-1 pathway in gastric epithelial cells.

\section{Conclusions}

$\alpha$-LA activates the Nrf2/HO-1 pathway by decreasing the interaction between Nrf2 and KEAP 1 and thus, reducing ROS levels and IL-8 expression in $H$. pylori-infected AGS cells. Consumption of $\alpha$-LA-rich foods may prevent the development of $H$. pylori-associated gastric inflammation.

Author Contributions: S.K. performed the research and wrote the paper. J.W.L. contributed new reagents and analytical tools. H.K. designed the research, analyzed the data, and edited the paper. All authors approved the manuscript in its current form.

Funding: This study was supported by a Brain Korea 21 PLUS Project, College of Human Ecology, Yonsei University, Seoul 03722, Republic of Korea.

Conflicts of Interest: The authors declare no conflict of interest.

\section{References}

1. Durrani, A.I.; Schwartz, H.; Nagl, M.; Sontag, G. Determination of free $\alpha$-lipoic acid in foodstuffs by HPLC coupled with CEAD and ESI-MS. Food Chem. 2010, 120, 1143-1148. [CrossRef]

2. Bilska, A.; Wlodek, L. Lipoic acid-the drug of the future. Pharmacol. Rep. 2005, 57, 570-577.

3. Jacob, S.; Ruus, P.; Hermann, R.; Tritschler, H.J.; Maerker, E.; Renn, W.; Augustin, H.J.; Dietze, G.J.; Rett, K. Oral administration of RAC-alpha-lipoic acid modulates insulin sensitivity in patients with type-2 diabetes mellitus: a placebo-controlled pilot trial. Free Radic. Biol. Med. 1999, 27, 309-314. [CrossRef]

4. Kamenova, P. Improvement of insulin sensitivity in patients with type 2 diabetes mellitus after oral administration of alpha-lipoic acid. Hormones 2006, 5, 251-258. [CrossRef]

5. Fava, A.; Pirritano, D.; Plastino, M.; Cristiano, D.; Puccio, G.; Colica, C.; Ermio, C.; De Bartolo, M.; Mauro, G.; Bosco, D. The Effect of Lipoic Acid Therapy on Cognitive Functioning in Patients with Alzheimer's Disease. J. Neurodegener. Dis. 2013, 2013, 454253. [CrossRef]

6. Hager, K.; Kenklies, M.; McAfoose, J.; Engel, J.; Münch, G. Alpha-lipoic acid as a new treatment option for Alzheimer's disease-a 48 months follow-up analysis. J. Neural Transm. Suppl. 2007, 72, 189-193.

7. Choi, J.H.; Cho, S.O.; Kim, H. $\alpha$-Lipoic acid inhibits expression of IL-8 by suppressing activation of MAPK, Jak/Stat, and NF-KB in H. pylori-infected gastric epithelial AGS cells. Yonsei Med. J. 2016, 57, 260-264. [CrossRef]

8. Byun, E.; Lim, J.W.; Kim, J.M.; Kim, H. $\alpha$-Lipoic Acid Inhibits Helicobacter pylori-Induced Oncogene Expression and Hyperproliferation by Suppressing the Activation of NADPH Oxidase in Gastric Epithelial Cells. Mediat. Inflamm. 2014, 2014, 380830. [CrossRef]

9. Young, R.; Hayes, J.D.; Brown, K.; Wolf, C.R.; Whitelaw, C.B.A. Peroxiredoxin Gene Expression Signatures in Liver Reflect Toxic Insult. ASSAY Drug Dev. Technol. 2010, 8, 512-517. [CrossRef]

10. Kobayashi, A.; Kang, M.I.; Okawa, H.; Ohtsuji, M.; Zenke, Y.; Chiba, T.; Igarashi, K.; Yamamoto, M. Oxidative Stress Sensor Keap1 Functions as an Adaptor for Cul3-Based E3 Ligase To Regulate Proteasomal Degradation of Nrf2. Mol. Cell. Biol. 2004, 24, 7130-7139. [CrossRef]

11. Hayes, J.D.; McMahon, M.; Chowdhry, S.; Dinkova-Kostova, A.T. Cancer Chemoprevention Mechanisms Mediated Through the Keap1-Nrf2 Pathway. Antioxid. Redox Signal. 2010, 13, 1713-1748. [CrossRef]

12. Sherratt, P.J.; Pickett, C.B.; Nguyen, T. Regulatory mechanisms controlling gene expression mediated by the antioxidant response element. Annu. Rev. Pharmacol. Toxicol. 2003, 43, 233-260.

13. Lee, S.; Lim, M.-J.; Kim, M.-H.; Yu, C.-H.; Yun, Y.-S.; Ahn, J.; Song, J.-Y. An effective strategy for increasing the radiosensitivity of Human lung Cancer cells by blocking Nrf2-dependent antioxidant responses. Free Radic. Biol. Med. 2012, 53, 807-816. [CrossRef] 
14. Takagi, T.; Naito, Y.; Okada, H.; Ishii, T.; Mizushima, K.; Akagiri, S.; Adachi, S.; Handa, O.; Kokura, S.; Ichikawa, H.; et al. Lansoprazole, a Proton Pump Inhibitor, Mediates Anti-Inflammatory Effect in Gastric Mucosal Cells through the Induction of Heme Oxygenase-1 via Activation of NF-E2-Related Factor 2 and Oxidation of Kelch-Like ECH-Associating Protein 1. J. Pharmacol. Exp. Ther. 2009, 331, 255-264. [CrossRef]

15. Motterlini, R.; Foresti, R.; Bassi, R.; Green, C.J. Curcumin, an antioxidant and anti-inflammatory agent, induces heme oxygenase- 1 and protects endothelial cells against oxidative stress. Free Radic. Biol. Med. 2000, 28, 1303-1312. [CrossRef]

16. Ogborne, R.M.; Rushworth, S.A.; O'Connell, M.A. $\alpha$-Lipoic Acid-Induced Heme Oxygenase-1 Expression Is Mediated by Nuclear Factor Erythroid 2-Related Factor 2 and p38 Mitogen-Activated Protein Kinase in Human Monocytic Cells. Arterioscler. Thromb. Vasc. Biol. 2005, 25, 2100-2105. [CrossRef]

17. Koriyama, Y.; Nakayama, Y.; Matsugo, S.; Kato, S. Protective effect of lipoic acid against oxidative stress is mediated by KEAP1/Nrf2-dependent heme oxygenase-1 induction in the RGC-5 cell line. Brain Res. 2013, 1499, 145. [CrossRef]

18. Pellicano, R.; Ribaldone, D.G.; Fagoonee, S.; Astegiano, M.; Saracco, G.M.; Mégraud, F. A 2016 panorama of Helicobacter pylori infection: key messages for clinicians. Panminerva Med. 2016, 58, 304-317.

19. Buzás, G.M. Benign and malignant gastroduodenal diseases associated with Helicobacter pylori: a narrative review and personal remarks in 2018. Minerva Gastroenterol. Dietol. 2018, 64, 280-296. [CrossRef]

20. Pellicano, R.; Oliaro, E.; Fagoonee, S.; Astegiano, M.; Berrutti, M.; Saracco, G.; Smedile, A.; Repici, A.; Leone, N.; Castelli, A.; et al. Clinical and biochemical parameters related to cardiovascular disease after Helicobacter pylori eradication. Int. Angiol. 2009, 28, 469-473.

21. Negrini, R.; Savio, A.; Poiesi, C.; Appelmelk, B.; Buffoli, F.; Paterlini, A.; Cesari, P.; Graffeo, M.; Vaira, D.; Franzin, G. Antigenic mimicry between Helicobacter pylori and gastric mucosa in the pathogenesis of body atrophic gastritis. Gastroenterology 1996, 111, 655-665. [CrossRef]

22. Yamaoka, Y.; Kita, M.; Kodama, T.; Sawai, N.; Tanahashi, T.; Kashima, K.; Imanishi, J. Chemokines in the gastric mucosa in Helicobacter pylori infection. Gut 1998, 42, 609-617. [CrossRef]

23. Remick, D.G. Interleukin-8. Crit. Care Med. 2005, 33, S466-S467. [CrossRef]

24. Craig, P.M.; Territo, M.C.; Karnes, W.E.; Walsh, J.H. Helicobacter pylori secretes a chemotactic factor for monocytes and neutrophils. Gut 1992, 33, 1020-1023. [CrossRef]

25. Suzuki, H.; Miura, S.; Imaeda, H.; Suzuki, M.; Han, J.Y.; Mori, M.; Fukumura, D.; Tsuchiya, M.; Ishii, H. Enhanced levels of chemiluminescence and platelet activating factor in urease-positive gastric ulcers. Free Radic. Biol. Med. 1996, 20, 449-454. [CrossRef]

26. Naito, Y.; Yoshikawa, T. Molecular and cellular mechanisms involved in Helicobacter pylori-induced inflammation and oxidative stress. Free Radic. Biol. Med. 2002, 33, 323-336. [CrossRef]

27. Kim, S.H.; Lim, J.W.; Kim, H. Astaxanthin inhibits mitochondrial dysfunction and interleukin-8 expression in Helicobacter pylori-infected gastric epithelial cells. Nutrients 2018, 10, 1320. [CrossRef]

28. Crabtree, J.E.; Covacci, A.; Farmery, S.M.; Xiang, Z.; Tompkins, D.S.; Perry, S.; Lindley, I.J.; Rappuoli, R. Helicobacter pylori induced interleukin-8 expression in gastric epithelial cells is associated with CagA positive phenotype. J. Clin. Pathol. 1995, 48, 41-45. [CrossRef]

29. Smoot, D.T.; Elliott, T.B.; Verspaget, H.W.; Jones, D.; Allen, C.R.; Vernon, K.G.; Bremner, T.; Kidd, L.C.R.; Kim, K.S.; Groupman, J.D.; et al. Influence of Helicobacter pylori on reactive oxygen-induced gastric epithelial cell injury. Carcinogenesis 2000, 21, 2091-2095. [CrossRef]

30. Seo, J.Y.; Kim, H.; Kim, K.H. Transcriptional regulation by thiol compounds in Helicobacter pylori induced IL-8 production in human gastric epithelial cells. Ann. N. Y. Acad. Sci. 2002, 973, 541-545. [CrossRef]

31. Xia, D.; Zhai, X.; Wang, H.; Chen, Z.; Fu, C.; Zhu, M. Alpha lipoic acid inhibits oxidative stress-induced apoptosis by modulating of Nrf2 signalling pathway after traumatic brain injury. J. Cell. Mol. Med. 2019, 23, 4088-4096. [CrossRef]

32. Lee, D.C.; Choi, H.; Oh, J.M.; Lee, D.H.; Kim, S.W.; Kim, S.W.; Kim, B.G.; Cho, J.H.; Lee, J. Protective effects of $\alpha$-lipoic acid on cultured human nasal fibroblasts exposed to urban particulate matter. Int. Forum Allergy Rhinol. 2019, 9, 638-647. [CrossRef]

33. Sena, C.M.; Cipriano, M.A.; Botelho, M.F.; Seiça, R.M. Lipoic Acid Prevents High-Fat Diet-Induced Hepatic Steatosis in Goto Kakizaki Rats by Reducing Oxidative Stress Through Nrf2 Activation. Int. J. Mol. Sci. 2018, 19, 2706. [CrossRef] 
34. Sun, H.; Guo, X.; Wang, Z.; Wang, P.; Zhang, Z.; Dong, J.; Zhuang, R.; Zhou, Y.; Ma, G.; Cai, W. Alpha-lipoic acid prevents oxidative stress and peripheral neuropathy in nab-paclitaxel-treated rats through the Nrf2 signalling pathway. Oxid. Med. Cell Longev. 2019, 2019, 3142732. [CrossRef]

35. Li, Y.; Paonessa, J.D.; Zhang, Y. Mechanism of Chemical Activation of Nrf2. PLoS ONE 2012, 7, e35122. [CrossRef]

36. Gobert, A.P.; Verriere, T.; Asim, M.; Barry, D.P.; Piazuelo, M.B.; De Sablet, T.; Delgado, A.G.; Bravo, L.E.; Correa, P.; Peek, R.M.; et al. Heme oxygenase-1 dysregulates macrophage polarization and the immune response to Helicobacter pylori. J. Immunol. 2014, 193, 3013-3022. [CrossRef]

37. Ko, S.H.; Rho, D.J.; Jeon, J.I.; Kim, Y.-J.; Woo, H.A.; Kim, N.; Kim, J.M. Crude Preparations of Helicobacter pylori Outer Membrane Vesicles Induce Upregulation of Heme Oxygenase-1 via Activating Akt-Nrf2 and mTOR-IкB Kinase-NF-кB Pathways in Dendritic Cells. Infect. Immun. 2016, 84, 2162-2174. [CrossRef]

38. Paik, J.Y.; Lee, H.G.; Piao, J.Y.; Kim, S.J.; Kim, D.H.; Na, H.K.; Surh, Y.J. Helicobacter pylori infection promotes autophagy through Nrf2-mediated heme oxygenase upregulation in human gastric cancer cells. Biochem. Pharmacol. 2019, 162, 89-97. [CrossRef]

39. Gobert, A.P.; Verriere, T.; Sablet, T.; Peek, R.M.; Chaturvedi, R.; Wilson, K.T. Heme oxygenase-1 inhibits phosphorylation of the Helicobacter pylori oncoprotein CagA in gastric epithelial cells. Cell Microbiol. 2013, 15, 145-156. [CrossRef]

40. Buommino, E.; Donnarumma, G.; Manente, L.; De Filippis, A.; Silvestri, F.; Iaquinto, S.; Tufano, M.A.; De Luca, A. TheHelicobacter PyloriProtein HspB Interferes with Nrf2/Keap1 Pathway Altering The Antioxidant Response of Ags Cells. Helicobacter 2012, 17, 417-425. [CrossRef]

41. Lock, R.A.; Cordwell, S.J.; Coombs, G.W.; Walsh, B.J.; Forbes, G.M. Proteome analysis of Helicobacter pylori: major proteins of type strain NCTC 11637. Pathology 2001, 33, 365-374. [CrossRef]

42. Nuhu, A.A. Bioactive Micronutrients in Coffee: Recent Analytical Approaches for Characterization and Quantification. ISRN Nutr. 2014, 2014, 384230. [CrossRef]

43. Liao, J.C.; Lee, K.T.; You, B.J.; Lee, C.L.; Chang, W.T.; Wu, Y.C.; Lee, H.-Z. Raf/ERK/Nrf2 signaling pathway and MMP-7 expression involvement in the trigonelline-mediated inhibition of hepatocarcinoma cell migration. Food Nutr. Res. 2015, 59, 29884. [CrossRef]

44. Sova, M.; Saso, L. Design and development of Nrf2 modulators for cancer chemoprevention and therapy: a review. Drug Des. Dev. Ther. 2018, 12, 3181-3197. [CrossRef]

45. Labbé, R.F.; Vreman, H.J.; Stevenson, D.K. Zinc protoporphyrin: A metabolite with a mission. Clin. Chem. 1999, 45, 2060-2072.

46. Hirai, K.; Sasahira, T.; Ohmori, H.; Fujii, K.; Kuniyasu, H. Inhibition of heme oxygenase-1 by zinc protoporphyrin IX reduces tumor growth of LL/2 lung cancer in C57BL mice. Intl. J. Cancer 2007, 120, 500-505. [CrossRef]

47. Fang, J.; Greish, K.; Qin, H.; Liao, L.; Nakamura, H.; Takeya, M.; Maeda, H. HSP32 (HO-1) inhibitor, copoly(styrene-maleic acid)-zinc protoporphyrin IX, a water-soluble micelle as anticancer agent: In vitro and in vivo anticancer effect. Eur. J. Pharm. Biopharm. 2012, 81, 540-547. [CrossRef]

48. Akopyants, N.S.; Jiang, Q.; Taylor, D.E.; Berg, D.E. Corrected Identity of Isolates ofHelicobacter PyloriReference Strain NCTC11637. Helicobacter 1997, 2, 48-52. [CrossRef]

49. Poppe, M.; Feller, S.M.; Romer, G.; Wessler, S. Phosphorylation of Helicobacter pylori CagA by c-Abl leads to cell motility. Oncogene 2007, 26, 3462-3472. [CrossRef]

50. Sharma, S.A.; Tummuru, M.K.; Miller, G.G.; Blaser, M.J. Interleukin-8 response of gastric epithelial cell lines to Helicobacter pylori stimulation in vitro. Infect. Immun. 1995, 63, 1681-1687.

51. Ikuta, N.; Okamoto, H.; Furune, T.; Uekaji, Y.; Terao, K.; Uchida, R.; Iwamoto, K.; Miyajima, A.; Hirota, T.; Sakamoto, N. Bioavailability of an R- $\alpha$-Lipoic Acid $/ \gamma$-Cyclodextrin Complex in Healthy Volunteers. Int. J. Mol. Sci. 2016, 17, 949. [CrossRef] [PubMed]

(C) 2019 by the authors. Licensee MDPI, Basel, Switzerland. This article is an open access article distributed under the terms and conditions of the Creative Commons Attribution (CC BY) license (http://creativecommons.org/licenses/by/4.0/). 